\title{
Notes on the vocalizations of Limestone Wren-babbler (Gypsophila crispifrons)
}

Peter Boesman

In the following we briefly analyze and compare voice of the three races of Limestone Wrenbabbler (Gypsophila crispifrons). We also try to quantify the extent of any vocal differences using the criteria proposed by Tobias et al. (2010), as a support for taxonomic review.

We have made use of sound recordings available on-line from Xeno Canto (XC) and Macaulay Library (ML).

Song of race calcicola is a short rising phrase of piercing whistles:
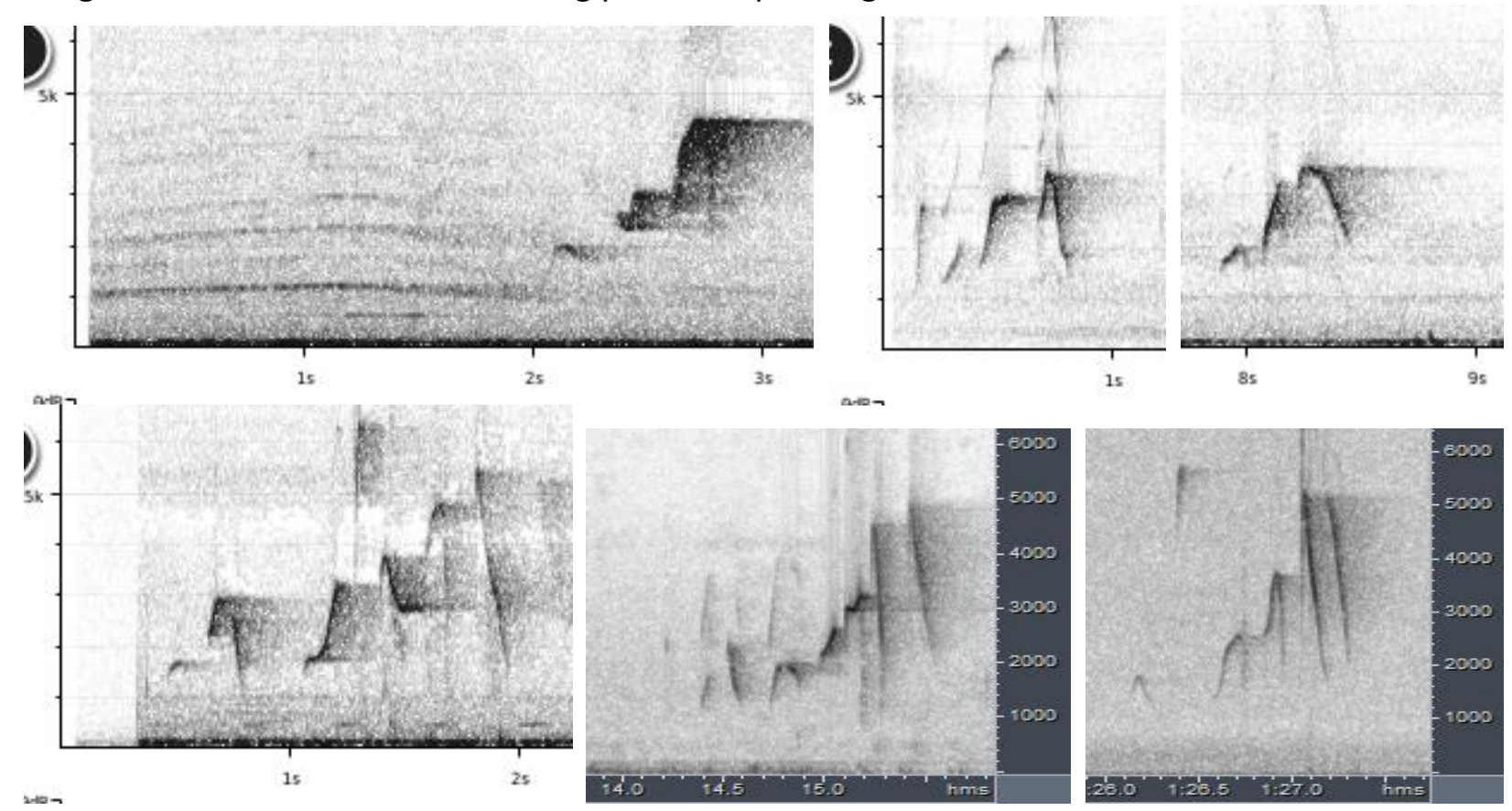

Only rarely a more continuous song is recorded:

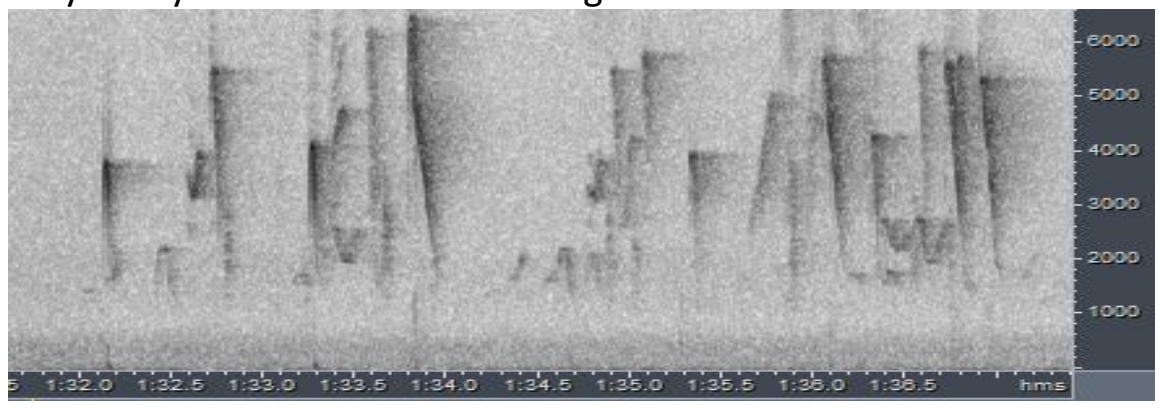




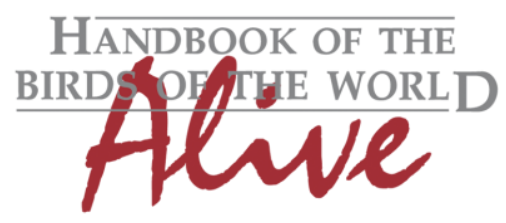

\section{ORNITHOLOGICAL NOTES}

Other races seem to have always a much longer song phrase with many more notes:

W Thailand (crispifrons)

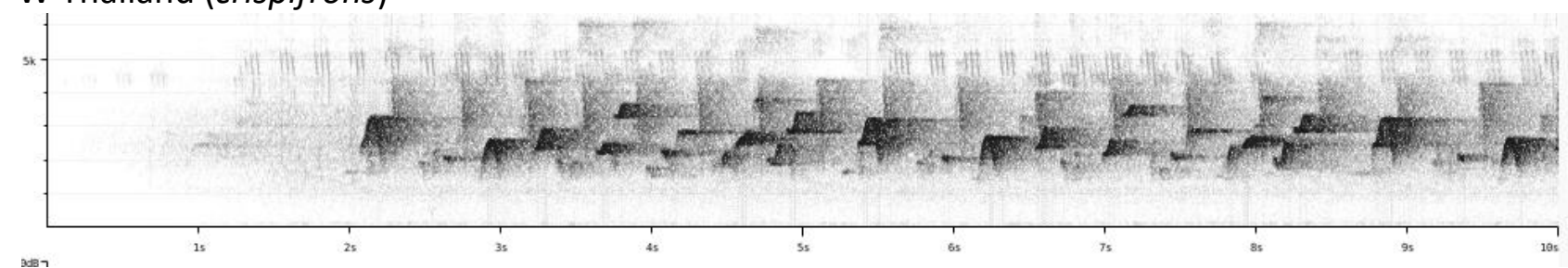

Vietnam (annamensis)
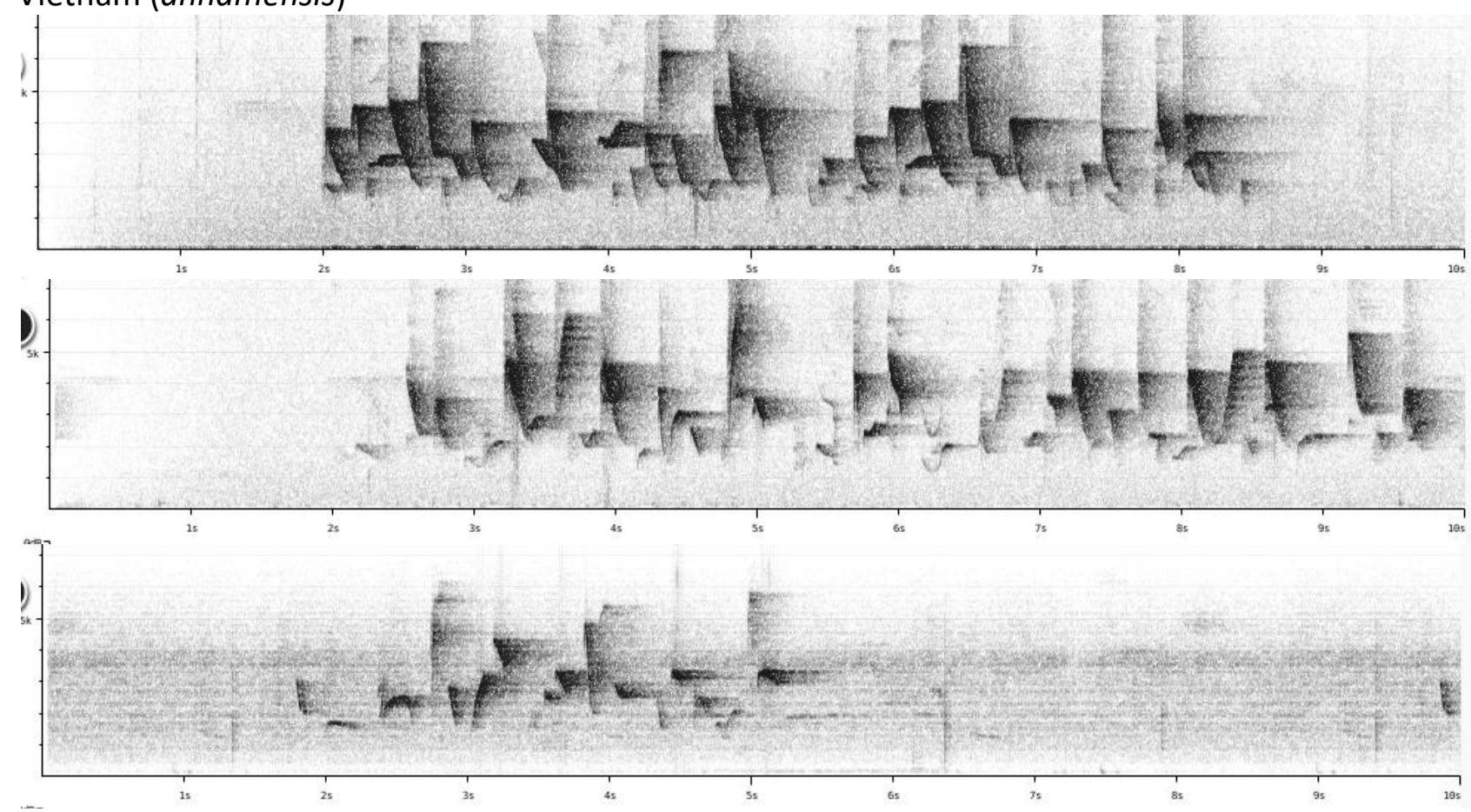

Notes of all races are similar-shaped, with abrupt whistles, many steeply upslurred or downslurred. The difference in song length and number of notes, based on the available recordings, is striking however. The song of calcicola is a short phrase of 3-6 notes and a duration of $0.7-1.5 \mathrm{~s}$ in almost all cases, while other races have a song phrase of 4-30s long with at least 16 notes, usually much more. While there may be a slight overlap considering calcicola utters sporadically a longer song phrase, based on average phrase length (2) and number of notes (2), application of Tobias criteria would lead to a total vocal score of about 4.

There are not enough recordings of calls available to make a useful comparison.

This note was finalized on 12th April 2016, using sound recordings available on-line at that moment. We would like to thank in particular the sound recordists who placed their recordings for this species on XC and ML: Marc Anderson, Mike Catsis, David Edwards, Peter Ericsson, Thijs Fijen, Frank Lambert, Linda Macaulay, Mike Nelson, Sander Pieterse, Craig Robson, Klemens Steiof and Arnoud van den Berg. 


\section{References}

Tobias, J.A., Seddon, N., Spottiswoode, C.N., Pilgrim, J.D., Fishpool, L.D.C. \& Collar, N.J. (2010). Quantitative criteria for species delimitation. Ibis 152(4): 724-746.

\section{Recommended citation}

Boesman, P. (2016). Notes on the vocalizations of Limestone Wren-babbler (Gypsophila crispifrons). HBW Alive Ornithological Note 270. In: Handbook of the Birds of the World Alive. Lynx Edicions, Barcelona. (retrieved from http://www.hbw.com/node/1251711 on 5 October 2016). 